KOŚCIÓŁ I PRAWO 9(22) 2020, nr 2, s. 159-174

DOI: http://dx.doi.org/10.18290/kip2092-11

\author{
Malwina Kędracka
}

\title{
LEGALIZACJA MAŁŻEŃSTW ZAWARTYCH W CERKWI PRAWOSŁAWNEJ
}

W obowiązującym porządku prawnym katolicy mogą zawierać ważne związki małżeńskie z chrześcijanami prawosławnymi w Cerkwi prawosławnej. Jest to konsekwencja kodeksowego wymogu zachowania $\mathrm{w}$ tym przypadku formy kanonicznej jedynie do godziwości. Zatem brak dyspensy od formy kanonicznej wydanej przez ordynariusza miejsca strony katolickiej nie wpływa na ważność małżeństwa. Obecnie wzrasta liczba małżeństw zawartych przed prawosławnym kapłanem z pominięciem wymogów stawianych przez prawo Kościoła katolickiego. Skutkuje to nie tylko nieuzyskaniem odpowiednich dokumentów, ale przede wszystkim nieprzeprowadzeniem badania kanoniczno-duszpasterskiego nupturientów, które ma na celu zweryfikowanie, czy nic nie stoi na przeszkodzie do ważnego i godziwego zawarcia małżeństwa. Niestety w wielu przypadkach Kościół katolicki w ogóle nie jest informowany o zawarciu małżeństwa mieszanego w Cerkwi, co może zagrażać dobru nie tylko poszczególnych wiernych, ale i w szerszym kontekście - całego Kościoła. Chociaż ustawodawca powszechny małżeństwom mieszanym, do których należą małżeństwa katolicko-prawosławne, poświęca dużo uwagi, to sam sposób legalizacji został uregulowany przez Konferencję Episkopatu Polski. Tym samym usankcjo-

Mgr lic. MALwina KęDRACKA, DOKTORANT - Katedra Kościelnego Prawa Procesowego, Małżeńskiego i Karnego oraz Katolickich Kościołów Wschodnich, Instytut Prawa Kanonicznego, Wydział Prawa, Prawa Kanonicznego i Administracji, Katolicki Uniwersytet Lubelski Jana Pawła II; e-mail: kedrackamalwina@gmail.com; https://orcid. org/0000-0002-6943-8268 
nowano kolejną procedurę, której może zostać poddane małżeństwo katolicko-prawosławne na forum Kościoła katolickiego.

\section{AKTUALNE USTAWODAWSTWO KOŚCIOŁA KATOLICKIEGO O ZAWIERANIU MAŁŻEŃSTW KATOLICKO-PRAWOSŁAWNYCH}

W Kodeksie Prawa Kanonicznego z 1983 r. ${ }^{1}$ odmienne wyznanie nie ma charakteru przeszkody wzbraniającej [Nowicka 2016, 212]. Nie oznacza to jednak, że nowe kodyfikacje pozostawiają całkowitą swobodę w zawieraniu małżeństw katolików z chrześcijanami prawosławnymi. Zgodnie z kan. 1124 KPK/83 małżeństwo między dwiema osobami ochrzczonymi, z których jedna została ochrzczona w Kościele katolickim lub po chrzcie została do niego przyjęta, druga zaś należy do Kościoła lub wspólnoty kościelnej niemającej pełnej łączności z Kościołem katolickim, jest zabronione bez wyraźnego zezwolenia kompetentnej władzy ${ }^{2}$. Wspomnianego zezwolenia, zgodnie z kan. $1125 \mathrm{KPK} / 83$, może udzielić ordynariusz miejsca, jeśli istnieje słuszna i rozumna przyczyna oraz zostaną spełnione kumulatywnie następujące warunki: 1) strona katolicka powinna oświadczyć na piśmie, iż jest gotowa odsunąć od siebie niebezpieczeństwo odejścia od wiary, jak również złożyć szczere przyrzeczenie, że uczyni wszystko, co w jej mocy, aby wszystkie dzieci zostały ochrzczone i wychowane w Kościele katolickim; 2) druga strona powinna być powiadomiona w odpowiednim czasie o składanych przyrzeczeniach strony katolickiej, tak aby rzeczywiście była świadoma treści przyrzeczenia i obowiązku strony katolickiej; 3) obie strony powinny być pouczone o celach i istotnych przymiotach małżeństwa, których nie może wykluczać żadna ze stron.

Przy zawarciu małżeństwa strona katolicka zobowiązana jest do zachowania przepisanej prawem formy kanonicznej. Niemniej, jeśli małżeństwo zawierane jest ze stroną niekatolicką obrządku wschodniego, kanoniczna forma zawarcia wymagana jest tylko do godziwości, do ważności zaś

${ }^{1}$ Codex Iuris Canonici auctoritate Ioannis Pauli PP. II promulgatus (25.01.1983), AAS 75 (1983), pars II, s. 1-317; tekst polski: Kodeks Prawa Kanonicznego, przekład polski zatwierdzony przez Konferencję Episkopatu, Pallottinum, Poznań 1984 [dalej cyt.: KPK/83].

2 Treść kanonu w brzmieniu nadanym przez: Benedictus PP. XVI, Litterae apostolicae motu proprio Omnium in mentem (26.10.2009), AAS 102 (2010), s. 8-10; tekst polski w: „L'Osservatore Romano” (wyd. pol.) 5 (2010), s. 13-14. 
konieczny jest udział kapłana, z zachowaniem innych wymogów prawa (kan. $1127 \S 1 \mathrm{KPK} / 83^{3}$ ). Z zawarciem małżeństwa katolicko-prawosławnego bez wymaganej przez prawo kanoniczne formy zawarcia małżeństwa zazwyczaj wiąże się brak przeprowadzenia badania kanonicznego nupturientów. Niemniej w takiej sytuacji istnieje domniemanie ważności małżeństwa, gdy zostało ono zawarte przy udziale kapłana. Powyższe wynika z kan. $1060 \mathrm{KPK} / 83$, zgodnie z którym małżeństwo cieszy się przychylnością prawa, dlatego w razie wątpliwości należy uważać je za ważne, dopóki nie udowodni się czegoś przeciwnego. Podstawą domniemania jest tutaj niewątpliwy fakt zawarcia małżeństwa w przepisanej formie [Jakubiak 2013, 127].

Charakter powyższej sankcji wynika z faktu, że Kościoły katolicki i prawosławny uznają wzajemnie ważność swoich sakramentów na podstawie nieprzerwanej sukcesji apostolskiej w odniesieniu do kapłaństwa i Eucharystii [Nowakowski 2007, 100].

Wspomniana powyżej sankcja niegodziwości jest charakterystyczna dla nomenklatury kościelnego porządku prawnego i często niezrozumiała dla wiernych. Oznacza ona w tym przypadku, że małżeństwo zostało zawarte przy zachowaniu jedynie wymogów warunkujących jego ważność, z jednoczesnym pominięciem przepisów prawa małżeńskiego odnoszących się do nupturientów, świadka urzędowego oraz formalności liturgiczno-prawnych [Pawluk 1984, 75].

Analizując kodeksowe regulacje dotyczące małżeństw mieszanych, warto pamiętać również o postanowieniach Dyrektorium ekumenicznego w sprawie realizacji zasad i norm dotyczących ekumenizmu z 25 marca 1993 r. ${ }^{4}$, którego rozdział czwarty pt. „Komunia życia i wspólne praktyki duchowe ochrzczonych" w znacznej części jest poświęcony sprawom małżeństw mieszanych. Skoro zaś małżeństwa te ze względu na swój charakter pozostają w optyce zainteresowania również Cerkwi prawosławnej, warto przybliżyć stanowisko prawosławia wobec małżeństw zawieranych przez chrześcijan prawosławnych z katolikami.

\footnotetext{
${ }^{3}$ Treść kanonu w brzmieniu nadanym przez: Franciscus PP., Litterae apostolicae motu proprio De concordia inter Codices (31.05.2016), AAS 108 (2016), s. 602-606.

${ }^{4}$ Pontificium Consilium ad Christianorum Unitatem Fovendam, Directorium de re oecumenica (25.03.1993), AAS 85 (1993), s. 1039-119.
} 


\section{ZAWARCIE MAŁŻEŃSTWA KATOLICKO-PRAWOSŁAWNEGO Z PERSPEKTYWY KOŚCIOŁA PRAWOSŁAWNEGO}

W Kościele prawosławnym jedność wiary, czyli włączenie w tenże Kościół, stanowi formalny warunek zawarcia małżeństwa wyznaniowego. Powyższe wynika jednoznacznie z uchwał Synodów w Laodycei (kan. 10 i 31), Kartaginie (kan. 21) oraz Czwartego (Chalcedon, kan. 14) i Szóstego Soboru Ekumenicznego (Konstantynopolitański III, kan. 72), w których zawarto zakaz zawierania małżeństw pomiędzy prawosławnymi i osobami niewłączonymi do pełnej jedności z Kościołem prawosławnym [Meyendorff 1995, 60].

Niemniej jednak w praktyce większości lokalnych Kościołów prawosławnych $^{5}$, powołując się na zasadę oikonomii ${ }^{6}$ duszpasterskiej, zazwyczaj biskup udziela zgody na zawarcie małżeństwa między prawosławnymi i chrześcijanami nieprawosławnymi [Kałużny 2018, 175].

Powyżej wskazane stanowisko znalazło odzwierciedlenie w dokumencie pt. „Sakrament małżeństwa i przeszkody do jego zawarcia” przyjętym przez Święty i Wielki Sobór Kościoła prawosławnego na Krecie w 2016 r., który wskazał, że małżeństwo między prawosławnymi i nieprawosławnymi nie może być zawierane według reguł kanonicznych (akrybii) (72. Kanon Soboru Trullańskiego). Jednakże może być ono zawierane ze względu

\footnotetext{
${ }^{5}$ Kościół prawosławny jest rodziną samodzielnych Kościołów lokalnych, pozostających w jedności wiary, sakramentów i zasad kanonicznych, które wyodrębniły się z chrześcijaństwa w XI w. w wyniku zerwania jedności kościelnej Wschodu i Zachodu. Kościoły te uznają siedem pierwszych soborów powszechnych i zachowują obrządek bizantyjski [Kałużny 2012, 19]. Kościoły prawosławne należy odróżnić od Kościołów przedchalcedońskich, które w terminologii przyjętej przez Światową Radę Kościołów noszą nazwę Oriental Orthodox Churches, w odróżnieniu od chalcedońskich Kościołów bizantyjsko-prawosławnych, dla których przyjęto nazwę Eastern Orthodox Churches [Przekop 1983, 279].

${ }^{6}$ Zamiast precyzyjnej i systematycznej definicji oikonomii, tradycja prawosławna oferuje kilka opisów i analogii, które rzucają światło na różne aspekty jej natury i funkcji. Ta kanoniczna zasada jest opisana pod względem elastyczności, sprężystości i zdolności adaptacyjnych. Rozważania Interoortodoksyjnej Komisji Przygotowawczej mówią o „zmodyfikowanym i elastycznym stosowaniu prawa kanonicznego”, podczas gdy Meyendorff pisał, że oikonomia stanowi żywą elastyczność, która wykracza poza legalistyczną interpretację danej sytuacji [Schembri 2017, 95]. Reasumując, oikonomia stanowi czasowe i doraźne odejście od ścisłości stosowania przepisu z racji pastoralnych. Można ją wstępnie określić jako pastoralną postawę Kościoła wobec ludzi, podyktowaną wyrozumiałością, łagodnością, miłosierdziem i troską o dobro duchowe [Kałużny 2018,11$]$.
} 
na wyrozumiałość i miłość do człowieka, pod warunkiem, że dzieci zrodzone $\mathrm{z}$ tego małżeństwa zostaną ochrzczone i wychowane w Kościele prawosławnym (nr 5.a). Stosowanie ekonomii kościelnej zostaje określone przez Święty Synod każdego autokefalicznego Kościoła prawosławnego, zgodnie z zasadami wynikającymi z kanonów kościelnych, w duchu duszpasterskiej troski o zbawienie człowieka (nr 7) ${ }^{7}$.

Celem uzyskania zgody na zawarcie małżeństwa mieszanego należy spełnić określone wymogi, które nie są jednolite we wszystkich lokalnych Kościołach prawosławnych [Kałużny 2018, 174]. Uzależnione są one w znacznej mierze od stanowiska Kościoła wobec małżeństw mieszanych. Rygorystyczne stanowisko prezentują Kościoły grecki i cypryjski, w których istnieje możliwość zawarcia małżeństwa pod dwoma warunkami: ważne małżeństwo mieszane może być zawarte (za zgodą biskupa) tylko w Kościele prawosławnym oraz obydwoje narzeczeni muszą złożyć obietnicę, że dzieci zostaną ochrzczone i wychowane w wierze prawosławnej [tamże, 175]. Wymagania te wpisują się w pogląd, zgodnie z którym, jeżeli ktoś z wyznawców prawosławnych otrzymuje sakrament małżeństwa poza swoim Kościołem, ten jasno świadczy, że nie jest godny pozostawać pośród wyznawców prawosławia. Błogosławieństwo małżeńskie wiernego prawosławnego $\mathrm{z}$ innym chrześcijaninem, udzielone przez nieprawosławnego kapłana, jest nieuznawane przez prawosławie, dopóki nie zostanie pobłogosławione przez kapłana prawosławnego [Hrycuniak 1994, 101].

Bardziej umiarkowane stanowisko prezentują Kościoły rosyjski i polski, które uznają ważność małżeństwa katolicko-prawosławnego zawartego przed kapłanem katolickim, po uprzednim uzyskaniu przez prawosławnego nupturienta zgody swojego biskupa. Przed uzyskaniem takiej zgody strona prawosławna musi złożyć deklarację o zachowaniu swojej wiary oraz obietnicę, że jego dzieci zostaną ochrzczone i wychowane w wierze prawosławnej [Kałużny 2018, 175].

Warto zwrócić uwagę, że niektóre Kościoły prawosławne uznają ważność małżeństw mieszanych zawartych w Kościele katolickim, o ile zostały one zawarte przed kapłanem, podczas gdy w katolicyzmie obecność kapłana w szczególnych sytuacjach nie jest nawet wymagana. Kościół łaciński

\footnotetext{
${ }^{7}$ Holly and Great Council of the Orthodox Church, The Sacrament of Marriage and its Impediments, w: Przed Soborem Wszechprawosławnym, red. T. Kałużny, Z. Kijas, Uniwersytet Papieski Jana Pawła II w Krakowie. Wydawnictwo Naukowe, Kraków 2016, s. 267-71.
} 
w celebracji małżeństwa nigdy nie zapomniał o elementach liturgicznych, podkreślając jednocześnie znaczenie momentu prawnego, konstytutywnego dla sakramentu, czyli wzajemnej zgody umawiających się stron, i w konsekwencji posługi małżonków w celebracji małżeństwa. Kościoły wschodnie dla tej samej celebracji kładą nacisk na ten szczególny moment, jakim jest święty obrzęd z błogosławieństwem kapłana, jako niezbędnym i nieodzownym elementem ważnej celebracji sakramentu. W związku z tym obie tradycje nie widzą w tej samej perspektywie wszystkich wymogów dotyczących ważnego sprawowania sakramentu. Łatwo więc zrozumieć, że pojęcie szafarza jest również inne, co wynika z odmiennej perspektywy tradycji teologiczno-prawnej [Kadzioch 1997, 227]. W tradycji prawosławnej tajemnica małżeństwa jest tworzona przez błogosławieństwo kapłańskie, czyli przez akt koronacji i towarzyszące mu modlitwy. $\mathrm{Z}$ tego powodu prawosławni nie uznają małżeństw cywilnych, małżeństw błogosławionych przez diakona prawosławnego, małżeństw zawartych bez udziału kapłana, dyspensowania od formy kanonicznej zawarcia małżeństwa, nadzwyczajnej formy zawarcia małżeństwa, małżeństw zawartych wobec nieprawosławnego kapłana, małżeństw zawieranych przez pełnomocnika i małżeństw po procedurze sanatio in radice [Schembri 2017, 55].

\section{PRZYCZYNY ZAWIERANIA NIEGODZIWYCH (NIELEGALNYCH) MAŁŻEŃSTW W CERKWI PRAWOSŁAWNEJ I NIEBEZPIECZEŃSTWO Z TYM ZWIĄZANE}

Chociaż w ustawodawstwie Kościoła katolickiego małżeństwa mieszane mogą być zawierane po spełnieniu określonych warunków, to praktyka pokazuje, że wiele z nich zostaje zawartych z pominięciem czynności prawnokanonicznych. Wydaje się, że przyczyn takiego stanu rzeczy jest co najmniej kilka i z całą pewnością nie jest to katalog zamknięty. Wśród przyczyn wynikających $\mathrm{z}$ relacji katolicko-prawosławnych można wskazać: wzajemną niechęć między duszpasterzami obu Kościołów przekładającą się na relacje $\mathrm{z}$ wiernymi; trudności i skomplikowana procedura związana z przygotowaniem narzeczonych do zawarcia małżeństwa mieszanego [Kraiński i Skolmowski 2019, 43-69]; świadomość problemów występujących w małżeństwach mieszanych związanych z odmienną konfesyjnością małżonków [Moroz 2014, 41-42]; mniej sformalizowane przygotowanie do 
zawarcia małżeństwa w Kościele prawosławnym. Z kolei najczęstszymi przyczynami leżącymi po stronie narzeczonych są: mniejsze zaangażowanie strony katolickiej w życie swojego Kościoła; niechęć do swojego proboszcza miejsca; przyjazne relacje $\mathrm{z}$ duszpasterzem prawosławnym; świadomość, że ze względu na „zdjęcie błogosławieństwa” z poprzedniego małżeństwa chrześcijanina prawosławnego, małżeństwo mieszane nie będzie uznane za ważne przez Kościół katolicki [Nowicka 2014, 125].

W konsekwencji powyżej wskazanych okoliczności Kościół katolicki najczęściej nie jest w ogóle informowany zarówno o planach narzeczonych w zakresie zawarcia małżeństwa mieszanego, jak i o samym fakcie jego zawarcia. Brak odnotowania zawarcia małżeństwa będzie powodował przeświadczenie, że katolik jest osobą stanu wolnego, co w świetle prawa umożliwi mu ewentualne zawarcie ponownego związku małżeńskiego w sytuacji, gdy w rzeczywistości będzie zachodziła zrywająca przeszkoda węzła małżeńskiego [Taż 2016, 163]. Wówczas strona katolicka dopuści się bigamii, co stanowi poważne naruszenie prawa Bożego.

Oprócz obaw i zagrożeń istnieją również pewne pozytywne aspekty tej, z całą pewnością niepożądanej, sytuacji. Chrześcijanin prawosławny może zdecydować się na włączenie do pełnej jedności z Kościołem katolickim. W przypadku, gdy do pełnej jedności z Kościołem katolickim przystępuje osoba ochrzczona poza nim, niezależnie od tego, kto przyjął od niej katolickie wyznanie wiary, osoba ta zachowuje odpowiedni obrządek wschodni $(\mathrm{nr} 4 . \mathrm{d})^{8}$. W przypadku zawarcia małżeństwa z katolikiem łacińskim i chęci praktykowania jego obrządku, małżeństwo umożliwia ujednolicenie obrządku zgodnie z zasadą, że kobieta zawsze może przejść na obrządek męża, natomiast tylko mężczyzna należący do Kościoła łacińskiego może przejść z takiego motywu na wschodni obrządek żony (nr 6.i). Chęć przystąpienia prawosławnego małżonka do pełnej łączności z Kościołem może zmotywować stronę katolicką do przemyśleń o swoim postępowaniu i jego skutkach.

Kolejnym pozytywnym aspektem jest właśnie fakt, że u części katolików, która zawarła małżeństwo mieszane bez dyspensy od formy kanonicznej, po jakimś czasie pojawia się refleksja, że to co zrobili nie jest

\footnotetext{
${ }^{8}$ Rada Prawna Konferencji Episkopatu Polski, Pro memoria dotyczace relacji duszpasterskich Kościoła łacińskiego z katolikami Kościołów wschodnich (04.10.2018), https://archidiecezjalubelska.pl/dokumenty-kep/ [dostęp: 10.10.2020].
} 
zgodne z nauką Kościoła i chcą uporządkować swój status na forum Kościoła katolickiego.

\section{PROCEDURA LEGALIZACJI MAŁŻEŃSTW ZAWARTYCH W CERKWI PRAWOSŁAWNEJ}

Istnienie realnych trudności związanych nie tylko z samym zapisaniem niegodziwie zawartego małżeństwa, ale przede wszystkim $\mathrm{z}$ weryfikacją, czy małżeństwo to może być uznane za ważne, było motywatorem do wypracowania prawnych rozwiązań $\mathrm{w}$ tym zakresie. $\mathrm{Z}$ całą pewnością $\mathrm{w}$ takiej sytuacji nie mogą mieć zastosowania przepisy KPK/83 dotyczące sanationis in radice, gdyż istnieje domniemanie ważności małżeństwa, przynajmniej jeśli chodzi o formę jego zawarcia [Adamowicz 2019, 7-29]. Należy jednak mieć na uwadze, że kan. $1127 \mathrm{KPK} / 83$ stanowi, że do ważności takiego małżeństwa konieczny jest udział kapłana, z zachowaniem innych wymogów prawa.

W związku z powyższym zaistniała konieczność wypracowania sposobu postępowania $\mathrm{w}$ tego typu sytuacjach, który umożliwiłyby odtworzenie przedmałżeńskiej sytuacji konkretnych osób i upewnienie się o braku przesłanek do stwierdzenia nieważności małżeństwa, czyli zachowaniu innych wymogów prawa. Chodzi tu o następcze stwierdzenie przyjęcia sakramentu chrztu, pozostawania w stanie wolnym, braku związania przeszkodami małżeńskimi oraz brak defektu w obszarze konsensu małżeńskiego [Tenże 2014, 70-77]. Z powyższych rozważań można wyprowadzić wniosek, że legalizacja małżeństw niegodziwie zawartych w Cerkwi prawosławnej jest procedurą zmierzającą do ustalenia braku wątpliwości w zakresie ważności zawartego małżeństwa poprzez następcze przeprowadzenie badania kanonicznego małżonków i, w przypadku braku tych wątpliwości, odnotowania faktu zawarcia tego małżeństwa w odpowiednich księgach parafialnych, co umożliwi zweryfikowanie statusu kanonicznego strony katolickiej i dopuszczenie jej do Komunii eucharystycznej.

Analizowane zagadnienie nie zostało uregulowane na szczeblu ustawodawstwa powszechnego. Przepisy odnoszące się do legalizacji małżeństw niegodziwie zawartych w Cerkwi prawosławnej zostały wskazane w dokumentach Konferencji Episkopatu Polski - Instrukcji o duszpasterstwie 
małżeństw o różnej przynależności kościelnej ${ }^{9}$ oraz Dekrecie ogólnym o przeprowadzaniu rozmów kanoniczno-duszpasterskich $z$ narzeczonymi przed zawarciem matżeństwa kanonicznego ${ }^{10}$.

\subsection{Stan prawny przed 1 czerwca 2020 roku}

Zgodnie $\mathrm{z}$ przepisami zawartymi $\mathrm{w}$ Instrukcji, w przypadku zawarcia przez stronę katolicką związku małżeńskiego w innym Kościele, duszpasterz powinien dołożyć starań, by pomóc uporządkować zaistniały stan rzeczy. Jeśli zawarcie związku małżeńskiego miało miejsce w Kościele prawosławnym, należy nakłonić stronę katolicką do naprawienia winy względem swego Kościoła w sakramencie pokuty, zażądawszy uprzednio złożenia w kancelarii parafialnej post factum oświadczenia i przyrzeczenia (IV.6.c). Duszpasterz jest zobowiązany do poczynienia odpowiednich kroków, by fakt ślubu (zwarcia małżeństwa) został odnotowany w metryce chrztu. Najlepszym rozwiązaniem byłoby dokonanie wspomnianej adnotacji na podstawie dokumentu wydanego przez proboszcza prawosławnego, a wyjątkowo - jeśli nie można takiego uzyskać - na podstawie zaprzysiężonego zeznania (IV.8).

Celem sposobu legalizacji zaproponowanego wówczas przez Konferencję Episkopatu Polski było przede wszystkim odnotowanie faktu zawarcia małżeństwa w Cerkwi prawosławnej, by następnie strona katolicka mogła naprawić swoją winę względem Kościoła w sakramencie pokuty ${ }^{11}$. W ra-

\footnotetext{
${ }^{9}$ Konferencja Episkopatu Polski, Instrukcia $w$ sprawie duszpasterstwa matżeństw o różnej przynależności kościelnej (14.03.1987), w: Dokumenty duszpastersko-liturgiczne Episkopatu Polski 1966-1993, red. Cz. Krakowiak, L. Adamowicz, Lubelskie Wydawnictwo Archidiecezjalne, Lublin 1994, s. 247-62 [dalej cyt.: Instrukcja].

${ }^{10}$ Taż, Dekret ogólny o przeprowadzaniu rozmów kanoniczno-duszpasterskich $z$ narzeczonymi przed zawarciem małżenstwa (17.03.2017), „Akta Konferencji Episkopatu Polski” 31 (2019), s. 28-93 [dalej cyt.: Dekret].

${ }^{11}$ Poprzez zawarcie niegodziwego małżeństwa w Cerkwi prawosławnej katolik dopuszcza się zakazanego uczestnictwa w rzeczach świętych, co na gruncie kościelnego prawa karnego stanowi przestępstwo (kan. 1365 KPK/83). Przez udział w kulcie liturgicznym należy rozumieć współuczestnictwo w czynnościach wykonywanych publicznie na cześć Boga, uporządkowanych według ksiąg, przepisów i zwyczajów jakiegoś Kościoła albo wspólnoty chrześcijańskiej, sprawowanych przez ich ministra lub delegata. Udział w sakramentach oznacza współuczestnictwo w sprawowaniu sakramentów Nowego Testamentu, które zostały ustanowione przez Chrystusa i powierzone Kościołowi [Gajda 2008, 122]. Kościół katolicki współudział w czynnościach świętych (communicatio in sacris) katolików z prawosławnymi zalicza do kategorii działań wiernych, które niosą ze sobą niebezpieczeństwo błędu, indyferentyzmu religijnego, a nawet porzucenia wiary [Syryjczyk 2003, 34]. W literaturze wskazuje się, że przestępstwo zakazanego
} 
mach przeprowadzanej procedury wskazane czynności nie wykraczały poza kompetencje duszpasterza i były dokonywane w kancelarii parafialnej, czyli zwyczajowym miejscu indywidualnego spotkania pasterza z powierzonymi mu wiernymi [Wenz 2008, 17]. W swojej istocie procedura ta nie dążyła do pełnej weryfikacji stanu rzeczy istniejącego przed zawarciem małżeństwa. Nie nakładała na duszpasterza obowiązku przeprowadzenia kanonicznego badania małżonków post factum, a więc po zawarciu małżeństwa. Czynności duszpasterza były znacznie ograniczone, a udział ordynariusza miejsca w ogóle pominięty.

Wydaje się, że podczas prac nad Instrukcją problemowi legalizacji małżeństw niegodziwie zawartych nie poświęcono zbyt wiele uwagi. Może to wynikać $\mathrm{z}$ faktu, że w latach 80 -tych ubiegłego wieku zjawisko to nie było zbyt powszechne. Za słusznością powyższego twierdzenia może przemawiać ilość opracowań poświęconych tej tematyce. Na tle innych zagadnień związanych z małżeństwami mieszanymi opracowań traktujących o legalizacji małżeństw niegodziwie zwartych było niewiele, ale ze względu na ich walor naukowy należy je obdarzyć uznaniem. Problem był sygnalizowany przez L. Adamowicza, który wspomniał o nim przy okazji przedstawiania zagadnienia prawno-liturgicznych aspektów zawierania małżeństw katolicko-prawosławnych [Adamowicz 2014, 80-81]. Wyczerpujące opracowanie tematu przygotował T. Jakubiak, który dokonał szerokiej analizy problemu małżeństw niegodziwie zawartych, wskazując na ich skutki nie tylko w prawie małżeńskim, ale również na płaszczyźnie karno-kanonicznej i na forum sumienia [Jakubiak 2013, 119-42].

Prace wyżej wymienionych kanonistów powstały w 2014 r. i 2013 r. i już wtedy wskazywano m.in. na konieczność weryfikacji post factum zdolności stron do ważnego zawarcia małżeństwa oraz odniesienia się do ordynariusza miejsca celem uzyskania dokumentu umożliwiającego zapisanie faktu zawarcia małżeństwa w księgach parafialnych, a więc na czynności znacznie wykraczające poza te wskazane w Instrukcji. Ich postulaty zostały uwzględnione w drugim z wyżej wymienionych dokumentów Konferencji Episkopatu Polski.

communicatio in sacris jest wielce szkodliwe i niebezpieczne dla Kościoła ze względu na jego bliski związek z przestępstwem herezji i schizmy. Dowodem tego jest fakt zamieszczenia go $\mathrm{w}$ dziale przestępstw skierowanych przeciwko wierze i jedności Kościoła w pierwszej kolejności za przestępstwem apostazji, herezji i schizmy (kan. 1364 KPK/83) [tamże, 35]. 
4.2. Legalizacja małżeństw - stan prawny po 1 czerwca 2020 roku

$\mathrm{Z}$ dniem 1 czerwca 2020 r. weszły w życie przepisy zawarte w Dekrecie, w tym nr 117, który został w całości poświęcony procedurze legalizacji małżeństw niegodziwe zawartych w Cerkwi prawosławnej. We wstępnej części przypomniano treść kan. $1127 \mathrm{KPK} / 83$, a następnie wskazano sposób postępowania w tego typu sytuacjach. Konferencja Episkopatu Polski prawnie usankcjonowała wymóg zweryfikowania, czy w związku z zawarciem małżeństwa w Cerkwi bez dyspensy od formy kanonicznej małżeństwa nie zostały naruszone zasady prawa Bożego oraz, czy strona katolicka spełniła wszystkie warunki do ważnego zawarcia małżeństwa. Czynności te mają poprzedzać dopuszczenie strony katolickiej do Komunii eucharystycznej.

W procedurze tej na stronie katolickiej ciąży obowiązek przedłożenia u proboszcza katolickiego parafii zamieszkania świadectwa ślubu zawartego w Cerkwi oraz świadectwa chrztu. Powinna ona również złożyć przyrzeczenie i oświadczenie (formularz 4), stosując odpowiednio przepisy odnoszące się do zawierania małżeństw mieszanych. Do obowiązków proboszcza własnego strony katolickiej należy sporządzenie protokołu rozmów kanoniczno-duszpasterskich z narzeczonymi, jaki zwykle sporządza się przed zawarciem małżeństwa, a następnie przekazanie tych dokumentów do kurii diecezjalnej celem uzyskania od ordynariusza miejsca uprawomocnienia tego małżeństwa na forum Kościoła katolickiego (formularz 12c). Na podstawie deklaracji ordynariusza miejsca proboszcz parafii zamieszkania małżonków sporządza akt małżeństwa w księdze parafialnej zaślubionych (kan. 1121 $\S 3 \mathrm{KPK} / 83$ ) oraz powiadamia parafię chrztu strony katolickiej o zawarciu przez nią małżeństwa w Cerkwi (kan. 1122 KPK/83).

Analiza nr. 117 Dekretu doprowadza do wniosku, że powyżej opisana procedura dzieli się na dwa etapy - pierwszy z nich odbywa się na poziomie parafii zamieszkania strony katolickiej (przepisy Instrukcji nie wskazywały duszpasterza właściwego do przeprowadzenia postępowania), drugi zaś - kurii diecezjalnej. Postępowanie w sytuacjach, w których zbiega się domniemanie o ważności zawartego małżeństwa oraz brak wiedzy na temat zdatności stron do zawarcia małżeństwa $\mathrm{z}$ pewnością nie będzie należało do najłatwiejszych [Jakubiak 2013, 119].

Podczas pierwszego etapu właściwy proboszcz obowiązany jest do odebrania od strony katolickiej przyrzeczenia i oświadczenia (o których w pierwszej części artykułu) oraz przeprowadzenia badania kanoniczno-duszpasterskiego. Stwierdzenie stanu wolnego oraz braku przeszkód 
w przypadku chrześcijanina prawosławnego, a także sporządzenie pism administracyjnych nawet $\mathrm{w}$ pożądanych warunkach (tj. podczas przeprowadzania badania kanonicznego przed zawarciem małżeństwa katolicko-prawosławnego) jest dla takiego duszpasterza źródłem wielu problemów i wątpliwości [Kraiński i Skolmowski 2019, 10]. W przypadku nupturientów prawosławnych najczęściej są one związane z faktem, że chrześcijanie prawosławni nie traktują nierozerwalności małżeństwa jako absolutnego wymogu prawa, ale raczej w perspektywie ideału moralnego. Jeśli jednak małżonkowie do tego ideału nie dojrzeli, to w określonych przypadkach Kościół prawosławny, kierując się zasadą „ekonomii kościelnej”, zezwala na rozwód i ponowne małżeństwa rozwiedzionych [Kałużny 2010, 51]. W Kościele katolickim sakramentalne małżeństwo jest nierozerwalne, co skutkuje brakiem uznawania stanu wolnego rozwiedzionych prawosławnych. $\mathrm{Z}$ tego względu duszpasterz powinien upewnić się, że prawosławny małżonek $\mathrm{w}$ istocie mógł być uznany za osobę stanu wolnego w świetle nauki i dokumentów Kościoła katolickiego oraz nie wykluczył nierozerwalności podczas wyrażania konsensu małżeńskiego [Kraiński i Skolmowski 2019, 66]. Trudność duszpasterzom może sprawiać również wynikający z kan. 780 § 2 Kodeksu Kanonów Kościołów Wschodnich ${ }^{12}$ obowiązek respektowania prawa małżeńskiego strony prawosławnej. Kościół prawosławny, w porównaniu do Kościoła katolickiego, nie posiada uniwersalnego kodeksu prawa kanonicznego, w którym mogliby znaleźć przepisy prawa małżeńskiego, z tego względu musieliby sięgnąć do ustawodawstwa konkretnego autokefalicznego Kościoła prawosławnego, z którego pochodzi prawosławny nupturient, a w tym przypadku małżonek, i dodatkowo jeszcze rozeznać, które przepisy obowiązują, a które już nie [Przekop 1977, 83].

Chociaż wprawdzie nowe regulacje o tym nie stanowią, to wydaje się wskazane, by proboszcz wraz ze zgromadzonymi dokumentami przesłał do kurii diecezjalnej również swoją opinię odnośnie do prawidłowości wyrażenia i trwania zgody małżeńskiej oraz nieistnienia niebezpieczeństwa rozejścia się [Adamowicz 2014, 183].

Drugim etapem, i zarazem kolejną wprowadzoną nowością, jest obowiązek zwrócenia się do ordynariusza miejsca strony katolickiej. Rozwiązanie

\footnotetext{
${ }^{12}$ Codex Canonum Ecclesiarum Orientalium auctoritate Ioannis Pauli PP. II promulgatus (18.10.1990), AAS 82 (1990), s. 1045-363; tekst polski: Kodeks Kanonów Kościołów Wschodnich promulgowany przez papieża Jana Pawła II, tłum. L. Adamowicz, M. Dyjakowska, Wydawnictwo Archidiecezji Lubelskiej Gaudium, Lublin 2002.
} 
to jest słuszne z co najmniej kilku powodów i z pewnością umożliwi efektywniejsze monitorowanie sytuacji na terenie diecezji oraz podjęcie stosownych środków duszpasterskich w przypadku nagminności zawierania niegodziwych małżeństw. Należy mieć na uwadze, że prowadzenie postępowań w tego typu sytuacjach nie należy do codziennych obowiązków proboszczów, co skutkuje brakiem doświadczenia w rozwiązywaniu trudności z nimi związanych. Ponadto, bezsprzecznie ordynariusz miejsca dysponuje efektywniejszymi środkami umożliwiającymi wykrycie „defektu” formy, wady zgody lub przeszkód, które mogą mieć wpływ na ważność małżeństwa [Jakubiak 2013, 129-30]. Tego, czy deklaracja zostanie przez władzę kościelną wydana, nie można $\mathrm{z}$ góry przewidzieć. Ordynariusz miejsca przy podejmowaniu decyzji będzie kierował się nie tylko przepisami prawa, ale także własnym rozumieniem tego, co należy dla dobra dusz uczynić, adekwatnie do wymogów stawianych przez zasady moralności [Krukowski 1985, 136]. W związku z tym nie można wykluczyć sytuacji, w której po przeanalizowaniu całości sprawy uzna, że nie może wydać deklaracji umożliwiającej odnotowanie małżeństwa $\mathrm{w}$ księgach parafialnych. Być może zasadne, z uwagi na okoliczności, będzie zastosowanie innej procedury.

Kończąc rozważania na temat legalizacji małżeństw niegodziwie zawartych należy zwrócić uwagę na kwestie związane z obowiązywalnością obu dokumentów Konferencji Episkopatu Polski, a w związku z tym możliwością wykorzystania rozwiązań w nich wskazanych. Dekret nie uchyla Instrukcji, wobec czego powstaje pytanie, które przepisy należy stosować. Zasada lex retro non agit wskazywałaby na stosowanie nowych regulacji wobec małżeństw niegodziwie zawartych, których zawarcie miało miejsce po 1 czerwca 2020 r. - po dacie wejścia w życie Dekretu. Niemniej sposób postępowania przewidziany w Instrukcji jest najzwyczajniej niewystarczający i nie powinien być w praktyce wykorzystywany.

\section{ZAKOŃCZENIE}

Kościół katolicki uznaje ważność małżeństw katolicko-prawosławnych zawartych w Cerkwi prawosławnej bez dyspensy od formy kanonicznej, o ile zostały zachowane inne wymogi prawa niezbędne do jego ważności. Stanowi to przejaw pewnego uprzywilejowania małżeństw mieszanych, w których stronami są katolicy i prawosławni. Małżeństwa takie mogą być 
również ważnie i godziwie zawarte po uprzednim dokonaniu czynności przewidzianych przez prawo kanoniczne. Jednak coraz częściej wierni decydują się na zawarcie małżeństwa w Cerkwi prawosławnej bez jakiegokolwiek informowania o swoich planach katolickiego duszpasterza. Przyczyn takiego postępowania można wskazać wiele, czasami będą wynikać z napiętych relacji katolicko-prawosławnych, innym razem będą związane z osobistą sytuacją nupturientów. Niemniej jednak w tych okolicznościach katolicy sami stawiają się w trudnym położeniu. Ze względu na brak weryfikacji zdatności stron do małżeństwa jego ważność jest jedynie domniemana. Pojawiają się problemy ze sporządzeniem aktu małżeństwa oraz odnotowaniem faktu jego zawarcia w odpowiednich księgach. Reperkusje niegodziwie zawartego małżeństwa dotykają również bezpośrednio stronę katolicką i mają wpływ na jej status w Kościele.

Występowanie problemu niegodziwie zawartych małżeństw determinowało opracowanie sposobu postępowania w tego typu sytuacjach, które miałoby na celu uporządkowanie statusu katolika oraz zapobieżenie naruszeniom prawa Bożego. Rozwiązanie zostało zawarte w dwóch dokumentach Konferencji Episkopatu Polski, jednak analiza wcześniejszej regulacji oraz stanowiska kanonistów wskazują, że nie realizował w pełni założonego celu. $\mathrm{Z}$ tego też względu uprawnione jest założenie, że sposób postępowania określony w Dekrecie jest nową procedurą, której może zostać poddane małżeństwo katolicko-prawosławne na forum Kościoła katolickiego. Wstępnie wprowadzoną zmianę w tym zakresie można ocenić pozytywnie, jednak ze względu na krótkie obowiązywanie Dekretu i brak informacji o praktycznym zastosowaniu tej regulacji, trudno o pełną i jednoznaczną opinię.

\section{PIŚMIENNICTWO}

Adamowicz, Leszek. 2014. „Aspekt liturgiczno-prawny zawarcia małżeństwa katolików z prawosławnymi." W Kanoniczno-liturgiczne aspekty zawierania matżeństw mieszanych $i$ im podobnych, red. Urszula Nowicka, 69-81. Warszawa: Prymasowskie Wydawnictwo GAUDENTINUM.

Adamowicz, Leszek. 2019. „Prace Konferencji Episkopatu Polski nad nową regulacją przygotowania do zawarcia małżeństwa kanonicznego (cz. II).” Biuletyn Stowarzyszenia Kanonistów Polskich 32:7-29.

Gajda, Piotr. 2008. Sankcje karne $w$ Kościele $w$ świetle Kodeksu Prawa Kanonicznego Jana Pawła II oraz późniejszych zmian i uzupetnień. Tarnów: Wydawnictwo Diecezji Tarnowskiej Biblos.

Hrycuniak, Sawa. 1994. Prawosławne pojmowanie małżeństwa. Białystok: Bractwo Prawosławne św. Cyryla i Metodego. 
Jakubiak, Tomasz. 2013. „Naprawienie zaistniałego stanu rzeczy po zawarciu małżeństwa przez stronę łacińską ze stroną akatolicką obrządku wschodniego bez dyspensy od formy kanonicznej przy udziale świętego szafarza." Roczniki Nauk Prawnych 23, nr 4:119-42.

Kadzioch, Grzegorz. 1997. Il ministro del Sacramento del matrimonio nella tradizione e nel diritto canonico e orientale. Roma: Editrice Ponificia Universita Gregoriana.

Kałużny, Tadeusz. 2010. „Nierozerwalność małżeństwa w Kościele prawosławnym.” Sympozjum 19:41-60.

Kałużny, Tadeusz. 2012. Na drogach jedności. Dwustronne dialogi doktrynalne Kościoła rzymskokatolickiego na płaszczyźnie światowej. Kraków: Wydawnictwo Księży Sercanów.

Kałużny, Tadeusz. 2018. Oikonomia kościelna $w$ teorii i praktyce prawosławia. Poznań: Wydawnictwo Księży Sercanów.

Kałużny, Tadeusz, i Zdzisław Kijas. 2016. Przed Soborem Wszechprawosławnym. Kraków: Uniwersytet Papieski Jana Pawła II w Krakowie. Wydawnictwo Naukowe.

Kraiński, Wiesław, i Wojciech Skolmowski. 2019. Kanoniczne przygotowanie katolika rzymskiego do matżeństwa międzyobrzqddkowego, międzywyznaniowego i międzyreligijnego. Torun: Wydawnictwo Adam Marszałek.

Krukowski, Józef. 1985. Administracja w Kościele. Zarys kościelnego prawa administracyjnego. Lublin: Redakcja Wydawnictw KUL.

Meyendorff, John. 1995. Matżeństwo w prawosławiu. Lublin: Prawosławna Diecezja Lubelska i Chełmska.

Moroz, Anna. 2014, „Małżeństwa mieszane wyznaniowo - w stronę sekularyzacji czy akulturacji?" Pogranicze. Studia Społeczne t. 26, 31-47.

Nowakowski, Przemysław. 2007. „Kościół rzymskokatolicki w poszukiwaniu interkomunii z Kościołami odmiennych tradycji liturgicznych.” Ruch Biblijny i Liturgiczny 2:97-114.

Nowicka, Urszula. 2014. „Stwierdzenie stanu wolnego przed zawarciem małżeństwa w Kościele katolickim.” W Kanoniczno-liturgiczne aspekty zawierania matżenstw mieszanych $i$ im podobnych, red. Urszula Nowicka, 119-35. Warszawa: Prymasowskie Wydawnictwo GAUDENTINUM.

Nowicka, Urszula. 2016. „Przeszkoda węzła małżeńskiego.” W Przeszkody matżeńskie $w$ prawie kanonicznym, red. Wojciech Góralski, 163-98. Warszawa: Wydawnictwo UKSW.

Pawluk, Tadeusz. 1984. Prawo kanoniczne według Kodeksu Jana Pawła II. T. 3: Prawo matżeńskie. Olsztyn: Warmińskie Wydawnictwo Diecezjalne.

Przekop, Edmund. 1977. „Problem wspólnego kodeksu prawa kanonicznego dla Kościołów Prawosławnych.” Studia Płockie 5:173-83.

Przekop, Edmund. 1983. „Autonomia i autokefalia w praktyce i teorii starożytnych Kościołów orientalnych.” Częstochowskie Studia Teologiczne 11:279-93.

Schembri, Kevin. 2017. Oikonomia, Divorce and Remarriage in the Eastern Orthodox Tradition. Roma: Pontificio Intituto Orientale \& Valore Italiano.

Syryjczyk, Jerzy. 2003. Kanoniczne prawo karne. Część szczególna. Warszawa: Wydawnictwo UKSW.

Wenz, Wiesław. 2008. Kancelaria parafialna jako przestrzeń kościelnego posługiwania. Studium kanoniczno-pastoralne. Wrocław: PWT we Wrocławiu. 


\section{Legalizacja małżeństw zawartych w Cerkwi prawosławnej}

\section{Streszczenie}

Legalizacja małżeństw niegodziwie zawartych w Cerkwi prawosławnej jest nową procedurą, której może zostać poddane małżeństwo katolicko-prawosławne na forum Kościoła katolickiego. Wprowadzone Dekretem ogólnym KEP o przeprowadzaniu rozmów kanoniczno-duszpasterskich z narzeczonymi przed zawarciem małżeństwa rozwiązania $\mathrm{w}$ tej materii stanowią ulepszoną formę poprzednio obowiązującej regulacji. Procedura ta ma na celu zweryfikowanie post factum, czy nic nie stało na przeszkodzie do ważnego zawarcia małżeństwo oraz, w przypadku braku co do tego wątpliwości, odnotowanie faktu zawarcia małżeństwa w odpowiednich księgach parafialnych. Czynności te umożliwią prawidłowe ustalenie statusu kanonicznego katolika, a także mogą zapobiec poważnym naruszeniom prawa Bożego.

Słowa kluczowe: prawo małżeńskie; prawo partykularne; relacje katolicko-prawosławne; małżeństwa mieszane; procedura kościelna

\section{Legalization of the Marriages Celebrated into the Orthodox Church}

\section{Summary}

The legalization of illicit marriages entered into the Orthodox Church is a new procedural matter. The general decree of the Polish Episcopal Conference on the conduct of canonical and pastoral talks with spouses is the basis for this case. This procedure is to verify post factum is there nothing in the way to validity of the marriage. If there are no impediments, the fact of celebration of marriage should be noted in the appropriate parish marriage register. These activities will make way for the accurate identification of what Catholic has his or her status in the Church. It may also prevent from serious violation of the divine law.

Key words: matrimonial law; particular law; Catholic-Orthodox relations; mixed marriages; ecclesiastical procedure

Information about Author: Malwina KęDRACKA, J.C.L., Ph.D. STUdent - Department of the Church Procedural Law, the Matrimonial and Penal Law and the Law of Oriental Catholic Churches, Institute of Canon Law, Faculty of Law, Canon Law and Administration, the John Paul II Catholic University of Lublin; e-mail: kedrackamalwina@gmail.com; https://orcid.org/0000-0002-6943-8268 